УДК 793.31.077

DOI:

Магдалина Марушка, здобувач кафедри загальної та дошкільної освіти, викладач кафедри культурології та мистечької освіти Дрогобицького державного педагогічного університету імені Івана Франка

\title{
ОСОБЛИВОСТІ СТАНОВЛЕННЯ ХОРЕОГРАФІЧНИХ ШКІЛ НА ГАЛИЧИНІ У МІЖВОЄННИЙ ПЕРІОД
}

Стаття присвячена розгляду особливостей створення хореографічних шкіл на Галичині у міжвоєнний час (1919-1939 рр.). Хореографічні школи Галичини досліджуваного періоду були репрезентовані у всіх тогочасних стилях, формах та видах танцю (украӥнському народно-сценічному, класичному, модерному). Між ними існували взаємовпливи, простежсувалась синхронність у розробиі тематики й образності, спостерігалось збагачення виразових засобів. Розвиток хореографії на Галичині відображсав загальні закономірності поступу європейської танцювальної культури.

Ключові слова: хореографічна школа; хореографічна освіта; народно-сценічна хореографія; хореографічне мистеитво; міжвоєнний період.

Jim. 5.

Mahdalyna Marushka, Postgraduate Student of the General and Preschool Education Department Drohobych Ivan Franco State Pedagogical University

\section{THE FEATURES OF THE FORMATION OFTHE CHOREOGRAPHIC SCHOOLS IN HALYCHYNA IN THE INTERMILITARY PERIOD}

The choreographic schools in Halychyna of the studied period were represented in all the contemporary styles, forms and types of dance (Ukrainian folk-stage, classical, modern). There was an interplay between them, synchronicity was traced in the development of the topics and the imagery, there was an enrichment of expressive means.

In the interwar period, the classic dance in Halychyna was represented by artists whose names were known in the ballet world of Eastern Europe. The rich artistic experience of choreographers and leading performers of the ballet troupe of the theater made it possible to significantly increase the achievements of the pre-war stage in this sphere, and their creative activity helped to establish the status of Lviv as one of the ballet centers of Poland.

The process of development of the stage choreographic culture in Halychyna at the beginning of the 20th century was significantly revitalized by the influences of European modernism. The growing popularity of modern choreographic currents in Halychyna has actualized the organization of dance education in the respective direction. Significant role in mastering the basics of technics and stylistics of the modern dance was played by special courses created during the interwar period at secondary and higher musical and drama educational institutions, as well as courses organized by Ukrainian and Polish cultural and educational societies.

The scene of the Ukrainian folk dance in Halychyna was closely associated with the formation of the national musical and drama theater. The use of folk dance in musical drama and opera performances has created a favorable ground for the further development of theatrical forms of this type of choreography and its gradual affirmation as a self-sufficient stage genre. A characteristic feature of this process in Halychyna was an active appeal to samples of regional dance.

The development of choreography in Halychyna reflected the general patterns of progress of the European dance culture.

The Halyhcyna's choreographers have widely used the rich experience of the European countries in the field of theory and practice of learning preserving the national educational traditions.

Keywords: the choreographic school; the choreographic education; the folk-stage choreography; choreographic art; an interwar period.

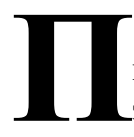

остановка проблеми. Культурномистецькі традиції України і сьогодні залишаються об'єктом уваги сучасних науковців. Адже одним із основних компонентів у системі професійної підготовки учителя хореографа є принцип взаємозв'язку загальної та професійної освіти майбутніх фахівців з погляду історичної ретроспективи. Відомо, що
1919 - 1939 рр. позначені пошуками нового змісту, методів, форм і засобів навчання та освіти. Науковці Галичини широко використовували багатий досвід європейських країн у галузі теорії та практики навчання, зберігаючи національні виховні традиції.

На становлення хореографічної освіти зазначеного періоду впливали загальноісторичні 
чинники та суспільно-історичні реалії (приналежність території до складу Польщі), тому розвиток хореографічної освіти відбувався у співвідношенні українсько-польських традицій. Саме уперіод “міжвоєнного двадцятиріччя” (1919 - 1939), в культурі зростає потреба у національній самоідентифікації духовного життя i, водночас, докорінно змінюються уявлення про засоби художнього відтворення, відбувається перегляд усталених класичних канонів танцю, оновлення жанрових та стильових систем, розширення їхньої виражальної палітри завдяки діяльності відомих реформаторів хореогафів: В. Авраменка,В.Верховинця, П. Вірського, К. Голейзовського, М. Мордкіна, Б. Ніжинської та ін. Творчо опановуючи новітні ідеї, в яких прокладала свій шлях історія європейської культури XX століття, кожен з них прагнув у своєму мистецтві зберегти найкращі здобутки вітчизняної школи танцю.

Таким чином актуальність дослідження визначається потребою обгрунтування особливостей розвитку хореографічної освіти на Галичині у міжвоєнний період у зв'язку 3 європейськими мистецькими процесами цього часу та українськими народно-танцювальними традиціями.

Мета статті - окреслити засади становлення хореографічних шкіл на Галичині у1919 - 1939 pp.

Аналіз останніх досліджень і публікацій. Історія становлення хореографічної освіти в Україні досліджена фрагментарно. Тільки тепер з'являються праці, опосередковано пов'язані із розвитком хореографічної освіти в Україні. Це дисертаційні дослідження С. Забредовського "Педагогічної мотиваційної сфери студентів хореографічних спеціалізацій в процесі фахової умови розвитку підготовки у вузі культури", О. Цвігун "Розвиток музичної освіти в навчальних закладах Києва (друга пол. XIX - поч. XX ст.)" та ін. Загалом література 3 питань історії хореографічної освіти в Україні є здебільшого навчальною i, як правило, не містить науковопізнавальних даних. На сьогодні практично відсутнє цілісне, узагальнююче наукове дослідження хореографічної освіти в Україні, його виникнення, становлення, еволюції тощо.

У історико-педагогічній літературі розробка проблеми розвитку хореографічних шкіл в Україні здійснювалась за декількома напрямками: українська балетна творчість і генеза балетного жанру (М. Загайкевич, В. Пасютинська, Ю. Станішевський), історія вітчизняного балетного театру (М. Загайкевич, М. Пастернакова, Ю. Станішевський), становлення школи української народно-сценічної хореографії (Г. Боримська,
О. Поясик, М. Загайкевич, В. Купленник, Ю. Станішевський), розвиток техніки та лексики українського народного танцю (В. Авраменко, К. Василенко, В. Верховинець, Р. Гарасимчук, А. Гуменюк), школи новітніх танцювальних течій (М. Пастернакова).

Окрему групу складають праці, присвячені творчості видатних балетмейстерів В. Авраменка, В. Верховинця, М. Соболя (Л. Барабан, П. Білаш, В. Коломієць, І. Книш, М. Коць, Р. Пилипчук, Ф. Погребенник, Ю. Станішевський).

Проте хореографічна культура Галичини у міжвоєнний період до цього часу не була предметом комплексного дослідження. В існуючих роботах фрагментарно висвітлені лише деякі аспекти іiі генези (М. Пастернакова, Н. Горбатова, І. Книш, В. Пастух та ін.).

Виклад основного матеріалу. Розвиток хореографічного мистецтва Свропи на початку $\mathrm{XX}$ століття позначений істотними зрушеннями, зумовленими вимогами часу: руйнуванням традиційних світоглядних пріоритетів, взаємодією художніх напрямів.

Новації в хореографії того часу великою мірою асоціюються й з іменами А. Дункан, Е. ЖакДалькроза, М. Вігман, Р. Лабана та інших митців, 3 ідеями котрих пов'язане становлення так званого “танцю модерн” на теренах Свропи та Америки. Цим поняттям охоплено різноманітні течії- від ритмопластики до “виразового” танцю. Діяльність адептів “модерну”, як і представників класичного балету, була спрямована на збагачення та оновлення танцювального мистецтва. “Однак модерні хореографи повністю або частково відкидали класичні танцювальні традиції, що зумовило концептуальні зміни творчих підходів і виявилось у трансформації хореографічної лексики, розробці елементів символіки та специфічному музичному оформленні постановок" [4].

Кожен із хореографів розробляв ідею оновлення танцювального мистецтва відповідно до власного бачення шляхів іiї реалізації. А. Дункан для танцювальних композицій використовувала твори камерної музики, здійснила модернізацію пластичної мови і реформутрадиційного костюму. Р. Лабан, спираючись на основні положення теорії сценічного руху Ф. Дельсарта, втілював у хореографічних постановках засади експресіонізму. Його послідовниця М. Вігман поглибила експресіоністичні знахідки Р. Лабана в напрямку максимального розширення виразових можливостей танцю [4]. Суттєвими художніми досягненнями була позначена й творчість інших представників експресіоністичного танцю - 
німецьких хореографів Г. Кройцберга, К. Йосса, Г. Палукки.

Дотриманням класичних танцювальних традицій характеризувався розвиток польської хореографічної школи наприкінці XIX - початку $\mathrm{XX}$ ст. Високим рівнем викладання відзначалась Варшавська балетна школа, що в цей період майже не поступалась петербурзькій та московській. Масштабні й помпезні класичні постановки здійснювались у Варшавському театрі, що посідав позиції одного з провідних в Європі. Проте усталеність його традиційного репертуару, зниження художнього рівня спектаклів й зростаюча еміграція кращих артистів свідчили про застійні явища у польському балеті. "Необхідність оновлення хореографічного мистецтва поступово усвідомлювалась польськими митцями, котрі намагались здійснювати його, насамперед, шляхом переосмислення естетики виконавства, протиставляючи самодостатньо акробатичній віртуозності внутрішню змістовність та виразність танцю” [4].

Істотними позитивними зрушеннями позначений початок 20-х років XX ст. Балетмейстер Варшавського театру П. Зайліх створив нову трупуі провів реорганізацію балетної школи при театрі. Він сформував різноманітний репертуар, що складався з відновлених й нових редакцій старих балетів, спектаклів з репертуару антрепризи С. Дягілева, власних версій балетів польських композиторів. У поставлених П. Зайліхом спектаклях широко використовувалися елементи національного танцювального фольклору, що в подальшому отримало продовження у польському балеті.

20 - 30-ті роки XX століття - якісно вищий етап розвитку вітчизняної хореографічної школи. Саме в цей період створювався і формувався балетний театр України як складова національної музично-театральної культури. Із становленням класичного танцювального мистецтва у 20 - 30-ті роки українська хореографія набула нових форм і пластичних барв: урізноманітнилася лексика як народного, так і класичного танцю, почався процес зростання технічної майстерності виконавців та професіоналізму балетмейстерів [2].

На початку XX ст. розвиток різних жанрів інструментальної музики спричинив народження на українській сцені симфонічних безсюжетних класичних балетів, в яких балетмейстери М. Дисковський, О. Горський, Л. Жуков, П. Вірський прагнули передавати високий поетичний i філософський зміст. Мистецькі шукання у зазначений період в усій їх різноманітності тяжіли до двох полюсів - традиціоналізму й новаторства.
Формуючись у контексті світових культурних процесів, враховуючи нові віяння в сценічному мистецтві, український класичний балет $20-30-x$ років XX ст. йшов шляхом нововведень: переглядалися традиційні балетні форми, образи, техніка; вносився новий зміст (“Коппелія” Л. Деліба, “Дон Кіхот” Л.Мінкуса, “Червоний мак” Р. Гліера, “Блазень” С. Прокоф’єва, “Фугболіст” В. Оранського тощо). “Злам старих форм, тимчасова відмова від виворітності, пальцевої техніки, використання танцювальної техніки на балетній сцені - це був етап закономірний, необхідний” [1].

Українська національна школа хореографії і система класичної хореографічної професійної освіти почала формуватися ще у XIX ст. Визначальний вплив на її розвиток мали, з одного боку - російська (петербурзька та московська) хореографічна школа, з іншого- західноєвропейська (французька й італійська, а також їх своєрідне поєднання - польська). Перші балетні студії та школи класичного танцю були створені С. Ленчевським у 1894 р. при Київській опері, що працювала до 1909 р., Н. Тальоні-Дудинською в 1915 р. при Харківській опері, Р. Баланотті в 1916 р. при Одеському оперному театрі. В 1915 р. велику школу в Києві заснувала головний балетмейстер опери Б. Ніжинська, вихованка Петербурзького хореографічного училища і учениця М. Фокіна, яка розгорнула підготовку професійних артистів. За радянської влади, а на Україні - з 1919 р., було започатковано систему закладів підготовки фахівців - танцівників і балетмейстерів, засновану на класичній хореографії. Враховуючи перебування України у складі Російської імперії, iї освітня сфера розвивалася як складова російської хореографічної освіти.

Так, наприкінці XIX ст. в Україні діяло 40 прогімназій, 43 чоловічих і 76 жіночих гімназій під патронажем Міністерства народної освіти, 4 гімназії відомства Імператриці Марії, 5 інститутів шляхетних дівчат, а також численні приватні заклади, програми яких дорівнювалися гімназійним і в яких викладалися уроки класичного і бального танців 3 гімнастикою. Активний розвиток української класичної хореографії й професійної освіти, що почався 31925 р. 3 відкриттям театрів опери та балету в Харкові 1925 р., Києві та Одесі з 1926 р., а потім уПолтаві, Вінниці, припадає на 30-ті роки. У цей період формується єдина радянська система хореографічної освіти 3 централізованим управлінням у Москві, розгалуженою системою підвідомчих крайових, регіональних, обласних, міських органів управління освітою на основі єдиної методики школи класичного танцю. 
У міжвоєнний період класичний танець на хореографи О. Гургула-Щуратова, О. ГерданГаличині репрезентований митцями, імена яких Заклинська, Г. Голубовська-Балтарович, були відомі у балетному світі Східної Свропи. Д. Кравців-Смець, Д. Нижанківська-Снігурович, Постановницька діяльність С. Фалішевського, О. Федак-Дрогомирецька та ін. "Самобутність їх О. Фортунато, Н. Кірсанової, А. Романовського, творчо-виконавського стилю полягала у розробці М. Статкевича, які працювали в цей період у Львівському Великому театрі, була позначена суттєвим впливом російського хореографічного мистецтва, зокрема, творчості М. Фокіна. “Це виявилось не тільки у прагненні до драматизації спектаклів, розробки характерів, посилення психологічної місткості й змістовності танцю, розширення його лексичного спектру" [3]. Багатий художній досвід згаданих хореографів та провідних виконавців балетної трупи театру (М. Вінтера, Е. Добецької, П. Добецького, 3. Патковського та ін.) дозволив значно примножити надбання довоєнного етапу у цій сфері, a їх творча діяльність сприяла утвердженню статусу Львова як одного з балетних центрів Польщі.

На засадах класичної хореографії, крім балетних вистав, створювались танцювальні сцени у суто розважальних театральних постановках - опереті та ревю. Популярність цих “легких" жанрів у міжвоєнні роки як у Свропі, так і у Галичині, відчутно зростала, що було зумовлено ïх демократичністю і яскравістю. Постановку хореографічних фрагментів у них, з врахуванням специфіки жанру, здійснювали провідні балетмейстери класичної школи С. Фалішевський, Й. Цесельський, Я. Цесарський та ін.

Завдання професійноїпідготовки танцюристів класичного профілю в міжвоєнний час виконували балетні школи-студії, що діяли при театрах (Великому й Театрі Новини у Львові, Театрі iм. С.Монюшка таукраїнському Театріім. І. Тобілевича у Станіславі); танцювальні школи при деяких навчальних закладах (наприклад, при Львівському музичному інституті); приватні хореографічні студії (С. Фалішевського і Т. Бурки, Л. ВаліцькоїЦесельської та ін.). Однак здобуття найвищої фахової кваліфікації на той час було можливе лише у Варшаві.

Процес розвитку сценічної хореографічної культури в Галичині на початку XX століття був значно пожвавлений впливами європейського модернізму. Нові танцювальні течії, що народжувались здебільшого в Німеччині та Австрії, захоплювали молодих прихильниць хореографії своєю оригінальністю, багатством художніх ідей та новою, цілком відмінною від класичної технікою. Яскравими творчими індивідуальностями серед плеяди визначних представників танцю “модерн” були українські новаційних ідей провідних зарубіжних митців 3 опорою на український танцювальний і музичний матеріал; нетрадиційна хореографічна образність здійснюваних постановок вимагали застосування оригінальних засобів пластичної виразності" [1].

Важливу роль у поширенні новітніх ідей відіграла діяльність М. Пастернакової. У iï численних статтях та рецензійних матеріалах, присвячених проблемам розвитку танцю “модерн”, аналізувалась творча діяльність, нововведення та здобутки провідних представників цього хореографічного напрямку та їх послідовників, висвітлювались характерні риси та особливості окремих танцювальних шкіл і течій, подавались відомості про досягнення українських хореографів у даній галузі.

Основною формою прилучення галицьких мистецьких й глядацьких кіл до надбань модерної хореографії в досліджуваний період були різнорідні показові виступи (хореографічні та пластичні імпрези; вечори танцю, музики і співу; дитячі хореографічні програми). Вони відзначались широким спектром представлених течій модерного танцю, що включав ритмопластику, експресіоністичний і виразовий танець, різнорідні стилізації. Участь у таких заходах брали не лише провідні галицькі виконавці, але й молодь переважно, вихованці місцевих хореографічних шкіл та студій. Кількість такого роду імпрез постійно зростала, їх характер урізноманітнювався. В 20-х роках серед них домінували заходи, в котрих поєднувались вокальні, інструментальні і танцювальні номери, в наступне десятиліття спеціальні хореографічні програми, розраховані на певну глядацьку аудиторію. Особливою популярністю користувались серед глядачів хореографічні мініатюри на музику українських авторів та європейських композиторів, модерні композиції на народно-танцювальній основі.

Зростаюча популярність модерних хореографічних течій у Галичині актуалізувала організацію танцювальної освіти відповідного спрямування. Значну роль в оволодінні основами техніки та стилістики модерного танцю відіграли створені у міжвоєнний період спеціальні курси при середніх та вищих музичних і драматичних навчальних закладах (Драматичній школі Ф. Фрончковського, Музичному закладі М. Рейсс, Львівському музичному інституті А. Нементовської, Консерваторії Польського музичного товариства, 
Вищому музичному інституті ім. М. Лисенка у м. Львові та ін.), а також курси, організовані українськими і польськими культурно-освітніми товариствами. Функції грунтовної фахової підготовки модерних танцюристів покладались на спеціальні приватні школи. Першу українську школу ритмопластики було засновано у Львові 1930 року О. Федів-Суховерською. Навчання здійснювалось за своєрідною методикою на основі української тематики, культивувались технічні навички “вільного” танцю та еуритміки. Вігманівська стилістика вивчалась у польських закладах м. Львова - Школі модерного танцю М. Броневської, Школі артистичного танцю М. Ржечицької-Вайдової. На засадах методики своїх вчителів працювали Б. Кац (навчалась у Г. Боденвізер) та українка О. ФедакДрогомирецька (учениця Е. Жак-Далькроза) - їх школи також функціонували у Львові. Організаційна структура подібних закладів була різноманітною і диференціювалась за предметом навчання, його професійним чи аматорським спрямуванням, віковими категоріями.

Отже, процес розвитку танцю “модерн” на Галичині в міжвоєнні роки був надзвичайно плідним і характеризувався висхідною динамікою. Оригінальний виконавський стиль українських представників модерного танцю формувався на грунті поєднання досвідузахідних хореографічних шкіл і традицій національного мистецтва. Значний творчо-виконавський потенціал українських хореографів розкрився у камерному жанрі, розвиток якого сприяв розширенню спектру національного i, водночас, збагаченню образнотематичних джерел європейського танцювального мистецтва. Активізація концертно-виконавського життя в краї, гастролі відомих хореографів і труп, а також заходи по забезпеченню фахової освіти стимулювали творчо-професійне зростання українських постановників й виконавців.

Сценізація українського народного танцю в Галичині була щільно пов'язана із становленням національного музично-драматичного театру. Використання народного танцю в музичнодраматичних і оперних виставах створило сприятливий грунт для подальшого розвитку театралізованих форм цього виду хореографії і його поступового утвердження як самодостатнього сценічного жанру. Характерною ознакою даного процесу у Галичині було активне звернення до зразків регіонального танцювального фольклору (зокрема гуцулки, аркана, коломийки) та введення їх в театральну практику. Найбільш виразно це демонструвала діяльність аматорского народного “Гуцульського театру” Г. Хоткевича (1909 - 1912), що в нових формах розвивав традиції народних видовищ. В постановках театру широко використовувався гуцульський танцювальний фольклор, дбайливо перенесений на сценув майже незмінному вигляді.

Вагомий внесок у подальший розвиток народно-сценічної хореографії у Галичині зробив Василь Авраменко, учень і послідовник В. Верховинця. Творчість балетмейстера, котрий навесні 1922 р. прибув до Львова, репрезентувала тенденцію до яскравої театралізації українського народного танцю. Це виявилось у прагненні хореографа до технічного ускладнення й довільної сценічної інтерпретації фольклорних першоджерел 3 акцентуалізацією на героїко-патріотичні мотиви. В. Авраменко впритул підійшов до створення своєрідних балетних спектаклів на народнотанцювальній основі, тим самим сприяючи піднесенню української сценічної хореографічної культури на якісно вищий щабель [5].

Усвідомлення балетмейстером значного потенціалу хореографічного мистецтва як засобу художнього і національного виховання молоді спонукало В. Авраменка до активної діяльності по організації в Галичині шкіл українського народного танцю. Заснувавши першу з них 1922 року у Львові, він згодом відкрив такі навчальні заклади майже в усіх більших містах Східної Галичини (Дрогобичі, Станіславі, Стрию, Тернополі та ін.). Викладання грунтувалось на системі хореографічного навчання, розробленій В. Авраменком на засадах школи В. Верховинця, програма шкіл передбачала опанування як практичного, так і теоретичного матеріалу. Прищеплюючи своїм вихованцям любов і повагу до національних танцювальних традицій, балетмейстер водночас готував їх до продовження розпочатої ним справи.

Хоч перебування В. Авраменка в Галичині не було тривалим (до осені 1924 року), його художньотворча діяльність істотно вплинула на подальший розвиток національної хореографічної школи і визначила регіональні особливості цього процесу.

Справу В. Авраменка продовжили його учні за підтримки численних українських громадських товариств Галичини. Духовно-виховний потенціал, притаманний українському народно-танцювальному мистецтву, осмислювався як відповідний головній меті цих інституцій - вихованню національної самосвідомості та піднесенню національної гідності українського громадянства. У зв'язку з цим товариства всіляко підтримували діяльність послідовників В. Авраменка, налагоджували тісну співпрацю з ними. Так Ф. Мацяк, Я. Булка, В. Тихоліз активізували у даному напрямку працю 
товариства 'Сокіл”, В. Терлецький, І. Магмет "Просвіти”, О. Бойчук, О. Заклинська, Р. Петріна - "Рідної школи" тощо. Крім постановки танців до різноманітних імпрез, хореографи проводили освітні курси та гуртки для бажаючих оволодіти мистецтвом народного танцю, публікували різноманітні фахові матеріали 3 даної проблематики у галицьких періодичних виданнях. В статтях В. Тихоліза, Я. Булки та інших авторів вміщувались відомості з історії українського народно-танцювального мистецтва, подавались практичні рекомендації та описи танцювальних зразків.

Велику теоретичну і практичну цінність для розвитку вітчизняної танцювальної культури мали опубліковані в міжвоєнний період дослідження етнографічного характеру (“Ягілки” О. Бариляка, “Гуцульські танці” Р. Гарасимчука), а також здійснені у цей період спроби українських хореографів узагальнити свій художній досвід у працях методично-репертуарного спрямування (“Рухові забави й гри з мелодіями і примівками" О. Суховерської, підготовані до друку рукописи "Матеріалів до вивчення українського національного танку” Р. Петріни та збірки танців і ритмічних забав для дітей ‘Молоданчик” О. Заклинської).

Великою заслугою українських постановників та педагогів було забезпечення основи для подальшого розвиткунаціонального танцювального мистецтва як органічної частини вітчизняної культури.

Висновок. Хореографічне мистецтво Галичини у міжвоєнний період було самобутнім, багатогранним й, водночас, цілісним явищем. Його розвиток відобразив загальні закономірності поступу європейської танцювальної культури. Суттєвий вплив художньо-творчих процесів, що мали місце у танцювальному мистецтві Свропи в перші десятиліття XX століття, виявився у створенні авторських танцювальних шкіл. Хореографічні школи Галичини досліджуваного періоду була репрезентовані у всіх тогочасних стилях, формах та видах танцю (українському народно-сценічному, класичному, модерному). Між ними існували взаємовпливи, простежувалась синхронність у розробці тематики й образності, спостерігалось збагачення виразових засобів.

\section{ЛІТЕРАТУРА}

1. Білаш П.М. Імпресіонізм у європейському танцювальному мистецтві початку ХХ століття. / П.М. Білаш // Вісник Міжнародного слов'янського університету. - Харків, 2003. T. VI. - № 2. - C.25-28.

2. Горбатова Н.О. Європейська хореографічна культура першої половини ХX століття (iсторіографічний аспект). / Н. Горбатова // Наукові записки. - К.: НПУ ім. Драгоманова, 2003. - Вип.54. - С. 234-243.

3. Горбатова Н.О. Розвиток хореографічної освіти в Україні (кінець XIX - початок XX ст.). / Н. Горбатова // Питання культурології: міжвідомчий збірник наукових статей. Випуск 17 / КНУКіМ. - К., 2001. - С. 6-12.

4. Пастух В. В. Модерні хореографічні напрямки в Галичині (20-30-ті рокі ХХстоліття). / В. Пастух //. - К.: Знання, 1999. - С. 38-41.

5. Поясик О. Фольклор в системі музичного виховання навчальних закладів Галичини (20-30-х рр. XX ст.). / О. Поясник // Актуальні проблеми української етнопедагогіки / За ред. чл.-кор. АПН України, проф. Скульського Р.П. - ІваноФранківськ, 2001. - С. 186-190.

\section{REFERENCES}

1. Bilash, P. M. (2003). Impresionizm $u$ yevropeiskomu tantsiuvalnomu mystetstvi pochatku XX stolittia [Impressionism of the European dance art at the beginning of the twentieth century. Herald of the International Slavic University]. Herald of the International Slavic University. Kharkiv, vol. 6, no.2, pp. 25-28. [in Ukrainian].

2. Horbatova, N.O. (2003). Yevropeiska khoreohrafichna kultura pershoi polovyny XX stolittia (istoriohrafichnyi aspekt) [European Choreographic Culture of the first half of the 20th Century (Historiographical Aspect)]. Proceedings. Kyiv: NPU im. Drahomanova, vol.54, pp. 234-243.[in Ukrainian].

3. Horbatova, N.O. (2001). Rozvytok khoreohrafichnoi osvity v Ukraini (kinets XIX - pochatok XX st.) [The development of choreographic education in Ukraine (at the end of the nineteenth and early twentieth centuries)]. The questions of cultural studies: interagency collection of scientific articles. Vol. 17. Kyiv, pp. 6-12.[in Ukrainian].

4. Pastukh, V. V. (1999). Moderni khoreohrafichni napriamky $v$ Halychyni (20-30-ti roki XX stolittia) [The modern choreographic directions in Galicia (2030th years of the XXth century)]. Kyiv: Znannia, pp. 38-41. [in Ukrainian].

5. Poiasyk, O. (2001). Folklor v systemi muzychnoho vykhovannia navchalnykh zakladiv Halychyny (20-30-kh rr. XX st.) [Folklore in the system of musical education of educational institutions of Galicia (20-30's of the twentieth century)].The actual problems of Ukrainian ethnopedagogy.(Ed.). Skulskyi R.P., IvanoFrankivsk, pp. 186-190. [in Ukrainian].

Стаття надійшла до редакції 23.07.2018 